\title{
HUBUNGAN JARAK DAN LAMA PAPARAN SINAR BIRU PESAWAT TELEVISI TERHADAP FUNGSI REFRAKSI PADA ANAK DI SEKOLAH DASAR GEREJA MASEHI INJILI DI MINAHASA 20 MANADO
}

\author{
${ }^{1}$ Eunike D. Toar \\ ${ }^{2}$ Jimmy Rumampuk \\ ${ }^{2}$ Fransisca Lintong \\ ${ }^{1}$ Kandidat Skripsi Fakultas Kedokteran Universitas Sam Ratulangi Manado \\ ${ }^{2}$ Bagian Fisika Fakultas Kedokteran Universitas Sam Ratulangi Manado \\ Email: euniqdebora@ymail.com
}

\begin{abstract}
Nowadays, watching television has become an integral part of children's daily activities. Albeit, TV can have a negative impact on their eyes due to the produced blue light. In the spectrum of light, this blue light is acceptable to the eye but it can cause eye damages by the free radicals produced. The risk of the damage depends on the light length and the exposure intensity. This study aimed to determine whether there is a correlation between the distance of watching TV and the duration of exposure to the blue light from TV with the refraction by measuring visual acuity. This was a cross-sectional study. The population was students of grade 1 to grade 5 of the GMIM 20 elementary school, Manado. Samples were 30 students who underwent visual acuity measurement. The results showed a $P$-value $>0.05$ by using a linear regression. The correlation of the distance of watching TV and the duration of exposure to the blue light with the visual acuity of the right eyes showed a $P$-value of 0.184 and of the left eyes a $P$-value of 0.967 . Conclusion: Among the GMIM 20 elementary school students in Manado there was no correlation between the distance of watching TV and the duration of exposure to the blue light of the television with eye refraction.
\end{abstract}

Keywords: television, blue light, exposure.

\begin{abstract}
Abstrak: Dewasa ini, televisi telah merupakan alat informasi dan hiburan yang terintegrasi dalam aktivitas keseharian anak-anak. Televisi bisa berdampak buruk bagi kesehatan mata akibat sinar biru yang dihasilkan. Sinar biru terdapat pada spektrum yang masih dapat diterima oleh mata, namun dapat menyebabkan kerusakan mata akibat oleh radikal bebas yang dihasilkannya. Risiko kerusakan mata tergantung pada panjang cahaya dan intensitas paparan. Penelitian ini bertujuan untuk mengetahui hubungan antara jarak dan lama paparan sinar biru pesawat televisi terhadap fungsi refraksi dengan melakukan pengukuran tajam penglihatan. Penelitian ini menggunakan cross-sectional design, dan mengikutsertakan siswa kelas 1 sampai kelas 5 SD GMIM 20 Manado sebagai populasi. Pada sampel sebanyak 30 siswa dilakukan pengukuran tajam penglihatan. Hasil penelitian dengan regresi linier memperlihatkan nilai $P>0,05$. Korelasi jarak dan lama paparan sinar biru televisi terhadap tajam penglihatan mata kanan memperlihatkan nilai $P=0,184$, dan terhadap tajam penglihatan mata kiri $P=0,967$. Simpulan: Tidak terdapat hubungan antara jarak dan lama paparan sinar biru pesawat televisi terhadap fungsi refraksi siswa di SD GMIM 20 Manado.
\end{abstract}

Kata kunci: televisi, sinar biru, paparan.

Dewasa ini, televisi telah mampu menarik minat penonton dan membuat yang menyaksikannya ketagihan untuk selalu menyaksikan berbagai acara yang ditayangkan. Bukan hanya orang dewasa saja, bagi anak-anak pun menonton tele- 
visi sudah merupakan bagian yang tidak terpisahkan dari aktivitas kesehariannya. ${ }^{1}$ The American Academy of Pediatrics ${ }^{2}$ merekomendasikan anak-anak diatas 2 tahun menggunakan kurang dari 2 jam per hari dengan layar media, karena banyak pandangan yang berhubungan dengan masalah akademik, perilaku, dan perkembangan sosial anak. Selain itu, televisi juga bisa mengganggu kesehatan mata anak. ${ }^{3}$ Aktivitas menonton televisi pada anak-anak juga mengurangi waktu bermain dan komunikasi sosial dengan orang tua atau saudara kandungnya. ${ }^{4}$ Penggunaan media televisi dilaporkan juga berkaitan dengan kejadian obesitas dan gangguan tidur. ${ }^{5}$ Penelitian Raghav dan Kumar $^{6}$ yang dilakukan di India tentang pengaruh televisi pada anak-anak dan remaja di daerah penduduk miskin perkotaan, menunjukkan rata-rata anak-anak menonton televisi 3,56 jam per hari. Jordan et al. mengamati bahwa banyak anak-anak menghabiskan kira-kira 3 jam perhari untuk menonton televisi. $^{2}$

Menonton televisi dan penggunaan komputer yang berlebihan akan meningkatkan gangguan refraksi pada anak. ${ }^{7}$ Sinar biru yang dipancarkan oleh televisi dan komputer mempunyai panjang gelombang 400-440 nm. ${ }^{8}$ Pada spektrum sinar, sinar biru masih dapat diterima oleh mata. Sinar ini bisa mencapai retina dan dapat menyebabkan kerusakan mata akibat radikal bebas yang dilepaskannya. ${ }^{9}$ Fotoreseptor retina rentan terhadap cedera dari cahaya, terutama sinar biru, ${ }^{10}$ dan dapat terjadi cedera fotokimia di retina. ${ }^{11}$

Risiko kerusakan pada mata yang terjadi tergantung dari panjang gelombang cahaya, intensitas, serta durasi paparan. Sinar biru juga dapat menyebabkan gangguan penglihatan seperti rabun jauh (miopia) pada anak-anak. Bayi dan anakanak sangat berpotensi terpapar sinar biru dalam aktivitasnya sehari-hari. ${ }^{3}$

Astuti et al. ${ }^{12}$ yang meneliti korelasi antara menonton televisi dan fungsi retina pada anak menyatakan bahwa sinar biru yang dipancarkan televisi dapat menyebabkan degenerasi retina. Penelitian tersebut dilakukan terhadap 106 murid sekolah dasar berusia 6-13 tahun dan menunjukkan bahwa semakin lama menonton televisi dengan jarak yang semakin dekat akan menurunkan fungsi retina mata pada anak. Televisi Cathode Ray Tube (CRT) cenderung lebih banyak memroduksi radiasi sinar. Perkembangan teknologi televisi telah mengikis bahkan meniadakan produksi televisi bertabung. ${ }^{13}$

\section{METODE PENELITIAN}

Penelitian ini bersifat observasional dengan desain cross sectional. Penelitian dilaksanakan pada pertengahan bulan November 2012-Januari 2013 dengan menggunakan teknik purposive sampling. Lokasi penelitian di SD GMIM 20 Manado pada siswa kelas 1-5.

Penjaringan sampel awal dilakukan melalui wawancara. Kriteria inklusi ialah: siswa yang menonton $>3$ jam per hari, jarak menonton $<4 \mathrm{~m}$, tidak mempunyai riwayat penyakit mata, tidak menggunakan kaca mata, serta kooperatif dan bersedia mengikuti penelitian dengan ijin orang tua. Sebagai kriteria eksklusi ialah: siswa yang memiliki aktifitas di luar rumah lebih banyak (jarang menonton televisi), tidak bersedia atau tidak kooperatif mengikuti seluruh rangkaian penelitian, memiliki gangguan mata di luar gangguan refraksi, sakit pada saat penelitian, dan pindah sekolah, tidak diikutsertakan dalam penelitian selanjutnya.

Pengukuran tajam penglihatan dinilai dengan Snellen chart. Kriteria penilaian tajam penglihatan: visus $6 / 6$ berarti dalam batas normal, sedangkan visus kurang dari 6/6 (misalnya, 6/12, 6/75, dsb) menunjukkan adanya penurunan tajam penglihatan.

\section{HASIL PENELITIAN}

Dari total 30 responden, sebanyak 24 responden $(80 \%)$ yang memiliki kebiasa-an menonton televisi setiap hari dan 6 responden $(20 \%)$ memiliki aktivitas menonton hanya beberapa hari dalam satu minggu (Tabel 1). 
Tabel 1. Intensitas menonton televisi.

\begin{tabular}{lcc}
\hline \multicolumn{1}{c}{$\begin{array}{c}\text { Intensitas } \\
\text { menonton }\end{array}$} & $\begin{array}{c}\text { Jumlah } \\
\text { responden }\end{array}$ & $\%$ \\
\hline -Setiap hari menonton & 24 & 80 \\
-Beberapa hari/minggu & 6 & 20 \\
Total & 30 & 100 \\
\hline
\end{tabular}

Keseluruhan responden menghabiskan waktu di depan televisi lebih dari lama yang dianjurkan, yakni sebanyak 17 responden $(56,7 \%)$ menonton $>4$ jam, 7 responden $(23,3 \%)$ menonton \pm 4 jam, dan 6 responden $(20 \%)$ menonton \pm 3 jam. (Tabel 2).

Tabel 2. Lama paparan dan jarak menonton responden terhadap televisi.

\begin{tabular}{ccc}
\hline $\begin{array}{c}\text { Lama } \\
\text { paparan }\end{array}$ & $\begin{array}{c}\text { Jumlah } \\
\text { responden }\end{array}$ & $\%$ \\
\hline 3 jam & 6 & 20 \\
4 jam & 7 & 23,3 \\
$>4$ jam & 17 & 56,7 \\
\hline
\end{tabular}

Sama halnya dengan jarak menonton, tidak seperti yang dianjurkan, karena yang menonton dengan jarak <1-2 m sebanyak 17 responden $(56,7 \%)$, dan $<1 \mathrm{~m}$ sebanyak 13 responden $(43,3 \%)$ (Tabel 3$)$.

Tabel 3. Jarak menonton responden terhadap televisi.

\begin{tabular}{ccc}
\hline $\begin{array}{c}\text { Jarak } \\
\text { menonton }\end{array}$ & $\begin{array}{c}\text { Jumlah } \\
\text { Responden }\end{array}$ & $\%$ \\
\hline $0-1 \mathrm{~m}$ & 13 & 43,3 \\
$1-2 \mathrm{~m}$ & 17 & 56,7 \\
\hline
\end{tabular}

Keluhan mata perih setelah atau sementara menonton televisi ditemukan pada 11 responden $(36,7 \%)$, keluhan lain (mata bengkak, berair) 2 responden $(6,7 \%)$, dan tidak ada keluhan 17 responden $(56,7$ $\%)$. Untuk aktivitas dengan layar media selain televisi (seperti playstation, telepon genggam, komputer, dsb) terdapat 24 responden $(80 \%)$ dan yang hanya menonton televisi saja dalam aktitivitasnya dengan layar media berjumlah 6 responden (20\%) (Tabel 4 dan 5).

Tabel 4. Keluhan responden sementara atau setelah menonton televisi.

\begin{tabular}{lcc}
\hline \multicolumn{1}{c}{ Jenis keluhan } & $\begin{array}{c}\text { Jumlah } \\
\text { responden }\end{array}$ & \% \\
\hline -Tidak ada keluhan & 17 & 56.7 \\
-Mata perih & 11 & 36.7 \\
-Keluhan lainnya (mata & 2 & 6.7 \\
bengkak, berair, dsb) & 30 & 100 \\
\hline
\end{tabular}

Tabel 5. Aktivitas dengan layar media.

\begin{tabular}{lcc}
\hline \multicolumn{1}{c}{$\begin{array}{c}\text { Aktivitas dengan } \\
\text { layar media }\end{array}$} & $\begin{array}{c}\text { Jumlah } \\
\text { responden }\end{array}$ & $\%$ \\
\hline -Hanya enonton televisi & 6 & 20 \\
-Playstation, handphone, & 24 & 80 \\
laptop, dll & 30 & 100 \\
Total &
\end{tabular}

Penelitian ini juga menggali data jenis televisi yang digunakan responden selama menonton di rumah (Tabel 6). Terbanyak 23 responden $(76,7 \%)$ menggunakan jenis televisi CRT yang cenderung lebih banyak efek radiasi sinar dari televisi itu sendiri, sedangkan yang menggunakan televisi layar datar (flat) sebanyak 7 responden $(23,3 \%)$.

Tabel 6. Jenis televisi yang digunakan responden ketika menonton televisi.

\begin{tabular}{ccc}
\hline $\begin{array}{c}\text { Jenis } \\
\text { televisi }\end{array}$ & $\begin{array}{c}\text { Jumlah } \\
\text { responden }\end{array}$ & $\%$ \\
\hline CRT & 23 & 76,7 \\
Flat & 7 & 23,3 \\
Total & 30 & 100 \\
\hline
\end{tabular}

Hasil analisis data dengan menggunakan regresi linear menunjukkan tidak ada hubungan antara jarak menonton dan lama paparan dengan fungsi refraksi yakni tajam penglihatan responden. Lama paparan dan jarak menonton tidak ber-hubungan dengan fungsi refraksi (tajam penglihatan) 
baik dengan mata kiri $(P=0,967>0,005)$, maupun mata kanan $(P=0,184)$.

Dari hasil pengukuran tajam penglihatan didapatkan hanya 5 responden saja yang mengalami penurunan tajam penglihatan. Penurunan tajam penglihatan dialami oleh responden dengan lama menonton $\geq 4$ jam atau lebih, juga dialami oleh yang menonton dengan jarak kurang dari $4 \mathrm{~m}(<2 \mathrm{~m})$.

\section{BAHASAN}

Penelitian ini bertujuan untuk mengetahui apakah terdapat keterkaitan intensitas lama paparan dan jarak menonton televisi terhadap fungsi refraksi anak. Direkomendasikan bahwa anak-anak hanya dapat menonton tidak lebih dari 3 jam per hari. $^{2}$ Hal ini disebabkan karena adanya sinar biru yang dipancarkan oleh pesawat televisi yang bisa membahayakan fungsi penglihatan.

Penelitian yang dilakukan pada anakanak di SD GMIM 20 Manado ini menunjukkan bahwa 24 responden berhadapan dengan pesawat televisi setiap harinya. Sebanyak 17 responden (56\%) menghabiskan waktu dengan televisi $>4$ jam. Penelitian ini juga menunjukkan bahwa 17 responden (56\%) menonton dengan jarak <4 m dari televisi, bahkan rata-rata menonton dengan jarak 1-2 m saja. Dari data kuisioner didapatkan adanya peningkatan keluhan mata perih pada anak yang menonton $>3$ jam dan dengan jarak $<4 \mathrm{~m}$. Anak-anak yang mengalami penurunan tajam penglihatan yaitu yang menonton dengan jarak $<2 \mathrm{~m}$ dan dengan lama menonton $>3$ jam. Hasil pengukuran tajam penglihatan menunjuk-kan hanya 4 responden yang mengalami penurunan tajam penglihatan mata kanan dan 2 responden yang mengalami penu-runan tajam penglihatan mata kiri.

Hasil penelitian ini hampir sama dengan penelitian Seema et al. mengenai efek menonton televisi pada penglihatan 1265 siswa sekolah berusia 6-15 tahun dengan mengukur tajam penglihatan memakai kartu Snellen. Siswa yang menonton televisi berjumlah 1172; 161 diantaranya memiliki gangguan tajam penglihatan. Sejumlah 109 siswa menonton televisi tanpa penerangan/ gelap; 24 diantaranya memiliki gangguan dalam penglihatan. Sebanyak 129 siswa yang menonton dengan jarak kurang dari 5 kaki; 27 siswa diantaranya mengalami gangguan tajam penglihatan. Sebanyak 914 siswa menonton televisi dengan jarak 5-10 kaki; 113 siswa diantaranya mengalami gangguan tajam penglihatan. Sebanyak 129 siswa yang menonton dengan jarak $>10$ kaki; 21 siswa diantaranya mengalami gangguan tajam penglihatan. Adanya penurunan tajam penglihatan sudah tentu mengganggu aktivitas belajar siswa. ${ }^{3}$

Hasil penelitian pada anak-anak di Sekolah Dasar GMIM 20 Manado dengan intensitas menonton lebih dari 3 jam dan dengan jarak $<4 \mathrm{~m}$, ternyata tidak menunjukkan hasil yang bermakna terdapatnya gangguan fungsi refraksi yang diuji melalui tajam penglihatan dengan Snellen Chart. Walaupun demikian, terdapat peningkatan keluhan mata perih pada 11 responden. Pemeriksaan lanjutan fungsi retina sangat disarankan dengan menggunakan alat-alat seperti funduskopi atau oftalmoskopi.

\section{SIMPULAN}

Dari hasil penelitian dapat disimpulkan bahwa tidak terdapat hubungan antara jarak menonton dan lama paparan sinar biru pesawat televisi terhadap fungsi refraksi pada anak-anak di SD GMIM 20 Manado.

\section{UCAPAN TERIMA KASIH}

Ucapan terima kasih disampaikan kepada Prof. dr. Vennetia R. Danes, M.Sc, $\mathrm{PhD}$ selaku penguji dan kepada semua pihak yang baik secara langsung maupun tidak langsung telah menumbuhkan ide atau gagasan dalam pemikiran penulis sehingga dapat menyelesaikan artikel ini.

\section{DAFTAR PUSTAKA}

1. Pitriawanti A. Pengaruh intensitas 
menonton televisi dan komunikasi orang tua - anak terhadap kedisiplinan anak dalam mentaati waktu belajar [Skripsi]. Semarang; Universitas Diponegoro; 2010.

2. Jordan AB, Hersey JC, McDivitt JA, Heitzler CD. Reducing children's television-viewing time: a qualitative study of parents and their children. Pediatrics. 2006;118(5):e1303-10.

3. Seema S, Vashisht BM, Khurana AK, Minakshi K, Manish G. Effect of television watching on vision of school children in rural Haryana [Serial online]. The Internet Journal of Preventive Medicine. 2011 [cited 2013 February 2];1(1). Available from: URL; http://www.ispub.com/journal/ the-internet-journal-of-preventivemedicine/volume-1-number-1/effectof-television-watching-on-vision-ofschool-children-in-rural-haryana.html \#sthash.OdLc9mrE.dpbs.

4. Schmidt ME, Pempek TA, Kirkorian HL, Lund AF, Anderson DR. The effects of background television on the toy play behavior of very young children. Child Dev. 2008; 79(4):1137-51.

5. Vandewater EA, Bickham DS, Lee JH. Time well spent? relating television use to children's free-time activities. Pediatrics. 2006; 117(2):e181-91.

6. Raghav P, Kumar A. The influence of television on children and adolescents in an urban slum. Indian J Community Med. 2010;35(3):447.

7. Rozanah, S. Deteksi dini kelainan mata pada anak (Aspek kesehatan anak). Seminar
Deteksi Dini Kelainan Mata pada Anak [homepage on the Internet]. Nodate [cited 2013 Aug 7]. Available from: http://www.pdpersi.co.id/website/bante n/data/kelainan_mata.pdf

8. Roberts JE. Ultraviolet radiation as a risk factor for cataract and macular degeneration. Eye Contact Lens. 2011;37(4):246-9.

9. Godley BF, Shamsi FA, Liang FQ, Jarrett SG, Davies S, Boulton M. Blue light induces mitochondrial DNA damage and free radical production in epithelial cells. J Biol Chem. 2005;280(22): 21061-6.

10. Shaban H, Richter C. A2E and blue light in the retina: the paradigm of agerelated macular degeneration. Biol Chem. 2002;383(3-4):537-45.

11. Okuno T, Saito H, Ojima J. Evaluation of blue light hazards from various light sources. Dev Ophtalmol. 2002;35:10412.

12. Harian Kompas. Menonton Televisi Turunkan Fungsi Retina Mata. c2008. [updated 2008 Jul 24; cited 2013 Aug 07]. Available from: http://nasional. kompas.com/read/2008/07/24/1942251 6/nonton.tv.turunkan.fungsi.retina.mata

13. Sherman CJ. Cathode ray tube displays. In: Webster JG, editor. The Measurement, Instrumentation and Sensors Handbook. USA: CRC Press; 1999.

14. Koide R, Ueda TN, Dawson WW, Hope GM, Ellis A, Somuelson D, et al. Retinal hazard from blue light emmiting diode. Nihon Ganka Gakkai Zasshi. 2001;105(10):687-95. 